Robert S. Helmer, PharmD BCPS; Allison M. Helmer, PharmD, BCACP; Sean Smithgall, PharmD, BCACP

Department of Pharmacy Practice, Auburn University Harrison School of

Pharmacy, Mobile, AL

DRsh0011@auburn.edu

The authors reported no potential conflict of interest relevant to this article.

\title{
Dual antiplatelet Tx for stroke prevention: Worth the risk?
}

\author{
Here's what the evidence tells us about the use of \\ 2 regimens-clopidogrel + aspirin and ER dipyridamole \\ + aspirin - to prevent secondary ischemic stroke.
}

\section{PRACTICE RECOMMENDATIONS}

$>$ Initiate combined clopidogrel plus aspirin within 24 hours of a minor stroke or TIA and continue for no longer than 1 month; then switch patients to aspirin or clopidogrel monotherapy. A

> Do not use combined clopidogrel plus aspirin for long-term secondary stroke prevention. A

$>$ Limit use of aspirin plus extended-release dipyridamole as a first choice for secondary stroke prevention because of limitations in efficacy and poor tolerability. (B)

Strength of recommendation (SOR)

A Good-quality patient-oriented evidence

B Inconsistent or limited-quality patient-oriented evidence

C Consensus, usual practice, opinion, disease-oriented evidence, case series
7 he incidence of ischemic stroke in the United States is estimated to be more than 795,000 events each year. ${ }^{1}$ After an initial stroke, the rate of recurrence is $5 \%$ to $20 \%$ within the first year, with the greatest prevalence in the first 90 days following an event. ${ }^{2-5}$ Although dual antiplatelet therapy, often with aspirin and a P2Y12 inhibitor such as clopidogrel, reduces the risk for recurrent cardiovascular events, cerebrovascular events, and death following acute coronary syndromes and percutaneous intervention, the role of combination antiplatelet therapy for secondary prevention of ischemic stroke continues to be debated. ${ }^{6}$ Reconciling currently available data can be challenging, as many studies vary considerably in both the time to antiplatelet initiation and duration of therapy.

For many years, aspirin alone was the drug of choice for secondary prevention of noncardioembolic ischemic stroke. ${ }^{7}$ Efficacy is similar at dosages anywhere between 50 and $1500 \mathrm{mg} / \mathrm{d}$; higher doses incur a greater risk for gastrointestinal hemorrhage. ${ }^{7}$ Current secondary prevention guidelines recommend a dosage of aspirin somewhere between 50 and $325 \mathrm{mg} / \mathrm{d}^{7}$

Alternative agents have also been evaluated for secondary stroke prevention, but only clopidogrel is currently considered an acceptable alternative for monotherapy based on a subgroup analysis of the CAPRIE (Clopidogrel versus Aspirin in Patients at Risk of Ischaemic Events) trial. ${ }^{7,8}$ Other alternatives, including cilostazol, ticlopidine, and ticagrelor, are limited by a lack of data, adverse drug reactions, or unproven efficacy and are not recommended in current guidelines. ${ }^{7,9}$ The ongoing THALES (Acute Stroke or Transient Ischaemic Attack Treated with Ticagrelor and Aspirin for Prevention of Stroke and Death) trial, assessing combination ticagrelor and aspirin, may identify an additional option for antiplatelet therapy following acute stroke. ${ }^{10}$

The current guidelines from the American Heart Asso- 
ciation/American Stroke Association (AHA/ ASA) support the combination of aspirin and extended-release dipyridamole (ASA-ERDP) as a long-term alternative to aspirin monotherapy. ${ }^{7,11}$ Additionally, the combination of clopidogrel and aspirin (CLO-ASA) is now recommended for limited duration in the early management of ischemic stroke. ${ }^{11}$

This review will explore the role of dual antiplatelet therapy for secondary prevention of noncardioembolic ischemic stroke or transient ischemic attack (TIA), with particular focus on acute use of CLO-ASA.

\section{Clopidogrel and aspirin:}

\section{When to initiate, when to stop}

The combined use of clopidogrel and aspirin has been well-studied for secondary prevention of ischemic stroke and TIA. However, interpreting and applying the results of these trials can be challenging given key differences in both time to treatment initiation and the duration of combination therapy. Highlights of the major randomized controlled trials (RCTs) evaluating the safety and efficacy of CLO-ASA are detailed in TABLE 1.,5,12-15

I Initial trials evaluating CLO-ASA for secondary stroke prevention, including the MATCH (Management of ATherothrombosis with Clopidogrel in High-risk patients), ${ }^{12}$ SPS3 (Secondary Prevention of Small Subcortical Strokes), ${ }^{13}$ and CHARISMA (Clopidogrel for High Atherothrombotic Risk and Ischaemic Stabilization, Management and Avoidance $)^{14}$ trials assessed the long-term benefits of combination therapy, with most patients initiating treatment a month or more following an initial stroke and continuing therapy for at least 18 months. ${ }^{12-14}$ Results from these trials indicate that long-term use (> 18 months) of CLO-ASA does not reduce recurrent events but increases rates of clinically significant bleeding. ${ }^{12-14}$

I A look at Tx timing. Since these initial attempts failed to show a long-term benefit with CLO-ASA, subsequent trials attempted to establish an appropriate balance between the optimal time to initiate CLO-ASA and the optimal duration of therapy. The FASTER (Fast Assessment of Stroke and Transient ischaemic attack to prevent Early Recurrence) trial was a small pilot study of 392 patients randomized to CLO-ASA or aspirin within 24 hours of stroke or TIA onset and continued for only 3 months. ${ }^{15}$ While this trial did not find a significant reduction in ischemic or hemorrhagic stroke with combination therapy, there was a large numerical difference in event rates between the 2 groups $(7.1 \%$ CLO-ASA vs $10.8 \%$ aspirin). ${ }^{15}$ An underpowered sample size (due to difficulty recruiting participants) is likely responsible for the lack of statistical significance. ${ }^{15}$ Despite the trial's failure to show a benefit with acute use of CLO-ASA, it suggested a possible benefit that led to further investigation in the CHANCE (Clopidogrel in High-risk patients with Acute Non-disabling Cerebrovascular Events $)^{5}$ and POINT (Platelet-Oriented Inhibition in New TIA and Minor Ischemic Stroke) ${ }^{4}$ trials.

The CHANCE trial conducted in China included more than 5000 patients with acute minor ischemic stroke (National Institutes of Health Stroke Scale [NIHSS] score $\leq 3$ ) or high-risk TIA (ABCD2 [a scale that assesses the risk of stroke on the basis of age, blood pressure, clinical features, duration of TIA, and presence or absence of diabetes] score $\geq 4$ ). ${ }^{5}$ Similar to FASTER, patients were randomized within 24 hours of symptom onset to CLO-ASA or aspirin. However, CHANCE utilized combination therapy for only 21 days, after which the patients were continued on clopidogrel monotherapy for up to 90 days; the aspirin monotherapy group continued aspirin for 90 days.

After 90 days, patients initially using combination therapy had significantly lower rates of ischemic or hemorrhagic stroke vs those assigned to aspirin monotherapy. This result was driven heavily by the reduction in ischemic stroke (7.9\% CLO-ASA vs $11.4 \%$ aspirin; $P<.001$ ). Additionally, there was no significant difference in moderate or severe bleeding events between the 2 groups. ${ }^{5}$ Efficacy and safety results were similar among a subgroup of patients who were randomized to treatment within 12 hours rather than 24 hours from symptom onset. ${ }^{16}$ The CHANCE trial was the first major study to demonstrate a clinical benefit of CLO-ASA to prevent recurrent stroke. Accordingly, the 2018 AHA/ ASA guidelines included a new recommen-
$>$

Patients who are best suited to benefit from clopidogrel + aspirin are those who have had minor noncardioembolic ischemic strokes or high-risk TIAs. 
TABLE 1

Clopidogrel and aspirin for recurrent stroke: A summary of RCTs

\begin{tabular}{|c|c|c|c|c|}
\hline Trial & Intervention & $\begin{array}{l}\text { Time to } \\
\text { treatment } \\
\text { onset }\end{array}$ & Outcomes/results & Notes \\
\hline $\begin{array}{l}\text { MATCH }^{12} \\
(2004)\end{array}$ & $\begin{array}{l}\text { CLO } 75 \mathrm{mg} \mathrm{+} \\
\text { ASA } 75 \mathrm{mg} \text { vs } \\
\text { CLO } 75 \mathrm{mg} \\
\text { Treatment/study } \\
\text { duration: } 18 \mathrm{mo}\end{array}$ & $\begin{array}{l}\text { Mean time: } \\
26 \mathrm{~d}\end{array}$ & $\begin{array}{l}\text { Primary efficacy endpoint } \\
16 \% \text { vs } 17 \%(P=N S) \\
\text { Life-threatening bleeding } \\
3 \% \text { vs } 1 \%(P<.0001) \\
\text { Major bleeding } \\
2 \% \text { vs } 1 \%(P<.0001)\end{array}$ & $\begin{array}{l}\text { NNH (life-threatening bleed) } \\
=50\end{array}$ \\
\hline $\begin{array}{l}\text { FASTER }^{15} \\
(2007)\end{array}$ & $\begin{array}{l}\text { CLO } 75 \mathrm{mg} \mathrm{+} \\
\text { ASA } 81 \mathrm{mg} \text { vs } \\
\text { ASA } 81 \mathrm{mg} \\
\text { Treatment/study } \\
\text { duration: } 90 \mathrm{~d}\end{array}$ & $\begin{array}{l}\text { Mean time: } \\
8.2-9.1 \mathrm{hr}\end{array}$ & $\begin{array}{l}\text { Primary efficacy endpoint } \\
7.1 \% \text { vs } 10.8 \%(P=N S) \\
\text { Symptomatic bleeding } \\
3 \% \text { vs } 0 \%(P=.03)\end{array}$ & $\begin{array}{l}\text { CLO loading dose: } 300 \mathrm{mg} \\
\text { Stopped early due to lack of } \\
\text { recruitment in a statin arm } \\
\text { substudy } \\
\mathrm{NNH}=34\end{array}$ \\
\hline $\begin{array}{l}\text { CHARISMA } \\
\text { substudy }{ }^{14} \\
(2011)\end{array}$ & $\begin{array}{l}\text { CLO } 75 \mathrm{mg}+ \\
\text { ASA } 75-162 \mathrm{mg} \text { vs } \\
\text { ASA } 75-162 \mathrm{mg} \\
\text { Treatment/study } \\
\text { duration (median): } \\
25 \mathrm{mo}\end{array}$ & $\begin{array}{l}31 \% \\
\text { randomized } \\
\text { within } 30 \mathrm{~d} \\
69 \% \\
\text { randomized } \\
\text { after } 30 \mathrm{~d} \\
\end{array}$ & $\begin{array}{l}\text { Primary efficacy endpoint } \\
4.9 \% \text { vs } 6.1 \%(P=N S) \\
\text { Severe bleeding } \\
1.9 \% \text { vs } 1.7 \%(P=N S)\end{array}$ & \\
\hline $\begin{array}{l}\text { SPS3 }^{13} \\
(2012)\end{array}$ & $\begin{array}{l}\text { CLO } 75 \mathrm{mg} \mathrm{+} \\
\text { ASA } 325 \mathrm{mg} \text { vs } \\
\text { ASA } 325 \mathrm{mg} \\
\text { Treatment/study } \\
\text { duration (mean): } \\
3.4 \text { y (range } \\
0-8.2 \text { y) }\end{array}$ & $\begin{array}{l}\text { Mean time: } \\
62 \mathrm{~d}\end{array}$ & $\begin{array}{l}\text { Primary efficacy endpoint } \\
2.5 \% / y \text { vs } 2.7 \% / y(P=N S) \\
\text { Major bleeding } \\
2.1 \% \text { vs } 1.1 \%(P<.001)\end{array}$ & $\begin{array}{l}\text { Only lacunar strokes included } \\
\text { All-cause mortality: } 2.1 \% / y \text { vs } \\
1.4 \% / y(P=.004) \\
\text { NNH }=100\end{array}$ \\
\hline
\end{tabular}

dation regarding secondary prevention for the use of CLO-ASA initiated within 24 hours and continued for 21 days following a minor stroke or TIA. ${ }^{11}$

A drawback of the CHANCE trial was its narrow patient population of only Chinese patients, which may limit applicability in clinical practice. There are known genetic variations in cytochrome P450 2C19 (CYP2C19) that may affect clopidogrel metabolism. CYP2C19 is responsible for the conversion of clopidogrel into its activated form in vivo. Carriers of a CYP2C19 loss-of-function allele may have reduced clopidogrel activation and subsequent reduced antiplatelet activity. Such loss-of-function alleles are more common in Asian populations vs non-Asian populations. ${ }^{17}$

A substudy of CHANCE found that CLO-ASA's efficacy benefit was preserved in noncarrier patients; however, patients with the CYP2C19 loss-of-function allele did not benefit from combination therapy. ${ }^{18}$ Interestingly, these genetic differences did not affect bleeding outcomes. Given that approximately $60 \%$ of patients in the CHANCE substudy were loss-of-function allele carriers and that the overall study results still showed benefit with combination therapy, application of CHANCE's findings to broader populations may not be a concern after all. ${ }^{18}$

In efforts to gain insight on CLO-ASA's use in a more diverse patient population, the POINT trial included almost 5000 patients, with $82 \%$ from the United States, who were randomized within 12 hours of symptom onset to CLO-ASA or aspirin monotherapy for 90 days. ${ }^{4}$ Similar to the CHANCE study, the POINT study included patients with mild ischemic strokes (NIHSS $\leq 3$ ) or high-risk 
TABLE 1

\section{Clopidogrel and aspirin for recurrent stroke: A summary of RCTs} (cont'd)

\begin{tabular}{|c|c|c|c|c|}
\hline Trial & Intervention & $\begin{array}{l}\text { Time to } \\
\text { treatment } \\
\text { onset }\end{array}$ & Outcomes/results & Notes \\
\hline $\begin{array}{l}\text { CHANCE }^{5} \\
(2013)\end{array}$ & $\begin{array}{l}\text { CLO } 75 \mathrm{mg}+ \\
\text { ASA } 75 \mathrm{mg} \text { vs } \\
\text { ASA } 75 \mathrm{mg} \text { for } 21 \mathrm{~d} \\
\text { Treatment/study } \\
\text { duration: } 90 \mathrm{~d} \\
(0-21 \mathrm{~d} \text { CLO-ASA vs } \\
\text { ASA; } 22 \text { - } 90 \mathrm{~d} \text { CLO } \\
\text { vs ASA) }\end{array}$ & $\begin{array}{l}\text { Mean time: } \\
13 \mathrm{hr}\end{array}$ & $\begin{array}{l}\text { Primary efficacy endpoint } \\
8.2 \% \text { vs } 11.7 \% \\
(P<.001) \\
\text { Moderate-to-severe } \\
\text { bleeding } \\
0.3 \% \text { vs } 0.3 \%(P=N S)\end{array}$ & $\begin{array}{l}\text { Included only minor strokes } \\
(72 \%) \text { and high-risk TIA ( } 28 \%) \\
\text { Randomized within } 24 \mathrm{hr} \text { of } \\
\text { index event } \\
\text { CLO loading dose: } 300 \mathrm{mg} \\
\text { Exclusively within Chinese } \\
\text { centers } \\
\text { NNT = } 29\end{array}$ \\
\hline $\begin{array}{l}\text { POINT }^{4} \\
(2018)\end{array}$ & $\begin{array}{l}\text { CLO } 75 \mathrm{mg}+ \\
\text { ASA } 81 \mathrm{mg} \text { vs } \\
\text { ASA } 81 \mathrm{mg} \\
\text { Treatment/study } \\
\text { duration: } 90 \mathrm{~d}\end{array}$ & $\begin{array}{l}\text { Mean time: } \\
7 \mathrm{hr}\end{array}$ & $\begin{array}{l}\text { Primary efficacy endpoint } \\
5 \% \text { vs } 6.5 \%(P=.02) \\
\text { Major bleeding } \\
0.9 \% \text { vs } 0.4 \%(P=.02)\end{array}$ & $\begin{array}{l}\text { Included only minor strokes } \\
(57 \%) \text { and high-risk TIA ( } 43 \%) \\
\text { Randomized within } 12 \mathrm{hr} \text { of } \\
\text { index event } \\
\text { CLO loading dose: } 600 \mathrm{mg} \\
\text { Stopped early due to } \\
\text { increased hemorrhage with } \\
83.6 \% \text { of anticipated patients } \\
\text { enrolled } \\
\text { NNT = } 67 \\
\text { NNH }=200\end{array}$ \\
\hline
\end{tabular}

ASA, aspirin; CLO, clopidogrel; NNH, number needed to harm; NNT, number needed to treat; NS, not significant; RCTs, randomized controlled trials; TIA, transient ischemic attack.

aFatal or nonfatal myocardial infarction, fatal or nonfatal ischemic stroke, other vascular death, rehospitalization for acute ischemic event.

${ }^{b}$ Any stroke (ischemic or hemorrhagic) within 90 days.

'Any stroke (ischemic or hemorrhagic).

dIschemic stroke, myocardial infarction, or death from ischemic vascular causes.

TIA (ABCD2 $\geq 4$ ). Combination therapy significantly reduced the primary endpoint of ischemic stroke, myocardial infarction (MI), or death from an ischemic event. Contrary to CHANCE, there was a significant increase in major bleeding in those assigned to combination therapy, which resulted in the trial being stopped early. ${ }^{4}$

A closer look at safety differences. CHANCE and POINT were the first major trials to show a benefit of CLO-ASA for secondary prevention of stroke, yet their differences in safety outcomes, specifically major hemorrhage, argued for a deeper reconciliation of their results. ${ }^{4,5}$ While both trials initiated secondary prevention within 24 hours of symptom onset, the difference in duration of combination therapy (21 days in CHANCE vs
90 days in POINT) likely impacted the rates of hemorrhage. When results from POINT were stratified by time period, particularly within the first 30 days of therapy (similar to the 21-day treatment duration of CHANCE), combination therapy significantly reduced the primary endpoint of ischemic stroke, MI, or death from an ischemic event (3.9\% CLOASA vs $5.8 \%$ aspirin; $P=.02$ ) without an increased risk for major hemorrhage. Between 30 and 90 days, this efficacy benefit disappeared. However, bleeding rates between groups continued to separate throughout the 90-day course. In this light, the 30 -day outcomes of POINT are largely similar to CHANCE and support the short-term use of CLO-ASA for secondary prevention without an associated increase in major bleeding. ${ }^{4,5}$ 


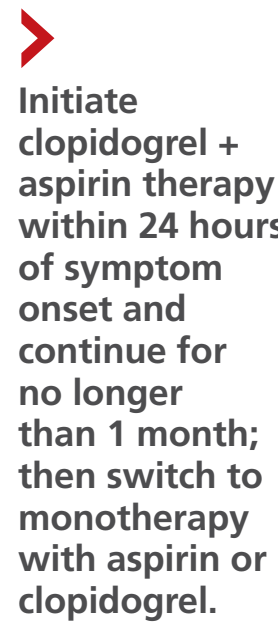

Initiate

clopidogrel + aspirin therapy within 24 hours of symptom onset and continue for no longer than 1 month; then switch to monotherapy with aspirin or clopidogrel.
I Antiplatelet dosing in POINT and CHANCE may also play a role in the contrasting safety results between the trials. ${ }^{4,5}$ While both studies utilized clopidogrel loading doses, POINT used $600 \mathrm{mg}$ while CHANCE used $300 \mathrm{mg}$. Clopidogrel maintenance dosing was the same at $75 \mathrm{mg} / \mathrm{d}$. In CHANCE, aspirin dosing was protocolized to $75 \mathrm{mg} / \mathrm{d}$; however, in POINT, $31 \%$ of patients used $>100 \mathrm{mg} / \mathrm{d}$ aspirin. ${ }^{4,5}$ It is possible that the higher doses of both aspirin and clopidogrel in the POINT trial contributed to the difference in the occurrence of major hemorrhage between the treatment groups in these trials.

I The takeaway. Based on currently available data, patients who are best suited to benefit from CLO-ASA are those who have had minor noncardioembolic ischemic strokes or high-risk TIAs. ${ }^{4,5,11}$ Clopidogrel should be given as a 300-mg loading dose followed by $75 \mathrm{mg} / \mathrm{d}$ given concomitantly with aspirin at a dose no higher than $100 \mathrm{mg} / \mathrm{d}$. CLO-ASA therapy should be initiated within 24 hours of symptom onset and be continued for no longer than 1 month, after which chronic preventive therapy with either aspirin or clopidogrel monotherapy should be started. ${ }^{4,5,11}$

\section{Dipyridamole and aspirin:}

\section{A controversial option}

Since the approval of the combination product ASA-ERDP, there has been considerable controversy about using this combination over other therapies, such as aspirin or clopidogrel, for recurrent ischemic stroke prevention. Much of this controversy arises from limitations in the trial designs.

The first trial to show benefit with ASA-ERDP was ESPS2 (European Stroke Prevention Study 2), which demonstrated superiority of the combination over placebo in reducing recurrent stroke when treatment was added within 3 months of an index stroke. ${ }^{19} \mathrm{~A}$ few studies have evaluated ASA-ERDP compared to aspirin monotherapy; however, most of these studies were small and did not show any difference in outcomes. ${ }^{20}$ Only ESPRIT (European/Australasian Stroke Prevention in Reversible Ischaemia Trial) ${ }^{21}$ carried significant weight in a 2013 meta-analysis, which showed a significant reduction in recurrent events with the combination product compared to aspirin monotherapy. ${ }^{20}$

Both the ESPS2 and ESPRIT trials had significant limitations. ${ }^{19,21}$ Patients in both studies had vascular comorbidities including atherosclerotic cardiovascular disease (ASCVD); however, pharmacotherapies designated to treat these diseases were not mentioned in the demographic data, nor were these medications taken into consideration to limit potential bias. ${ }^{19,21}$ Retrospectively, a significant proportion of aspirin doses utilized as a control in ESPRIT were inferior to the guideline-recommended dosing with $42 \%$ to $46 \%$ of patients receiving $30 \mathrm{mg} / \mathrm{d} .{ }^{21}$ Despite these controversies, ASA-ERDP is still considered an alternative to aspirin monotherapy in the guidelines. ${ }^{7}$

I The timing of ASA-ERDP initiation appears to be inversely related to the efficacy of the combination over therapeutic alternatives. Studies in which the therapy was initiated 3 to 6 months from the index stroke indicated favorable outcomes for the combination when compared to ASA or ERDP monotherapy. ${ }^{19,21}$ Studies utilizing early initiation (ie, within 24 or 48 hours of the index event) or even within 3 weeks showed no difference in outcomes; however, this may be due in part to the use of clopidogrel or other combination antiplatelet therapy as active comparators. $^{22-24}$

Early initiation of ASA-ERDP also demonstrated a higher risk of major and intracranial bleeding compared to clopidogrel. ${ }^{22}$ Additionally, use of triple therapy with ASAERDP plus clopidogrel increased bleeding events without improving efficacy. ${ }^{24}$ More recent studies of ASA-ERDP are focusing on earlier initiation of therapy; it is unknown whether the benefits of late initiation will be confirmed in future studies. Highlights of the major RCTs evaluating the safety and efficacy of ASA-ERDP are detailed in TABLE $2^{19,21-24}$.

I The takeaway. Methodological issues and potential confounding factors in many of the key trials for ASA-ERDP make it challenging to fully discern the role that ASAERDP may play in the secondary prevention 
TABLE 2

Aspirin and extended-release dipyridamole for recurrent stroke: A summary of RCTs

\begin{tabular}{|c|c|c|c|c|}
\hline Trial & Intervention & $\begin{array}{l}\text { Time to } \\
\text { treatment } \\
\text { onset }\end{array}$ & Outcomes/results & Notes \\
\hline $\begin{array}{l}\text { ESPS2 }^{19} \\
(1996)\end{array}$ & $\begin{array}{l}\text { ASA-ERDP } 25 / 200 \mathrm{mg} \\
\text { twice daily or ASA } \\
25 \mathrm{mg} \text { twice daily or } \\
\text { ERDP } 200 \mathrm{mg} \text { twice } \\
\text { daily vs placebo } \\
\text { Treatment/study } \\
\text { duration: } 2 \mathrm{y}\end{array}$ & $\begin{array}{l}\text { Treatment } \\
\text { within } 3 \text { mo of } \\
\text { index event }\end{array}$ & $\begin{array}{l}\text { Primary: } \\
\text { For ASA-ERDP vs placebo } \\
\text { Stroke }(\mathrm{OR}=0.59 ; 95 \% \mathrm{Cl}, 0.48- \\
0.73) \\
\text { Death }(\mathrm{OR}=0.90 ; 95 \% \mathrm{Cl} 0.73- \\
1.12 ; P=\mathrm{NS}) \\
\text { Stroke and/or death }(\mathrm{OR}=0.71 \text {; } \\
95 \% \mathrm{Cl}, 0.59-0.84)\end{array}$ & $\begin{array}{l}\text { Stroke NNT = } 18 \\
\text { Stroke and/or death NNT = } 18 \\
\text { ASA and ERDP monotherapy also } \\
\text { significantly reduced stroke and stroke } \\
\text { and/or death endpoints } \\
\text { Included patients with atrial fibrillation } \\
\text { (approximately } 6.5 \% \text { in each group) }\end{array}$ \\
\hline $\begin{array}{l}\text { ESPRIT }^{21} \\
(2006)\end{array}$ & $\begin{array}{l}\text { ASA-ERDP } 25 / 200 \mathrm{mg} \\
\text { twice daily vs ASA } \\
\text { (dosing varied) } \\
\text { Treatment/study } \\
\text { duration: Mean } 3.5 \mathrm{yr} \\
\text { (SD } 2 \mathrm{yr} \text { ) }\end{array}$ & $\begin{array}{l}\text { Treatment } \\
\text { within } 6 \text { mo of } \\
\text { index event }\end{array}$ & $\begin{array}{l}\text { Primary: } \\
\text { Composite death from vascular } \\
\text { cause, nonfatal stroke, } \\
\text { nonfatal } \mathrm{MI} \text {, major bleeding } \\
\text { complication } \\
\mathrm{HR}=0.8(95 \% \mathrm{Cl}, 0.66-0.98)^{\mathrm{a}} \\
\text { Secondary: } \\
\text { Death from all vascular causes } \\
\text { and nonfatal stroke } \\
\mathrm{HR}=0.78(95 \% \mathrm{Cl}, 0.62-0.97)^{\mathrm{a}} \\
\text { Death from vascular causes, } \\
\text { nonfatal stroke, nonfatal } \mathrm{MI} \\
\mathrm{HR}=0.78(95 \% \mathrm{Cl}, 0.62-0.97)^{\mathrm{a}}\end{array}$ & $\begin{array}{l}\text { Primary outcome NNT = } 34 \\
66 \%-69 \% \text { of patients randomized } \\
1-6 \text { mo from event } \\
42 \%-46 \% \text { of patients were on } 30 \mathrm{mg} / \mathrm{d} \\
\text { ASA }\end{array}$ \\
\hline $\begin{array}{l}\text { PROFESS } 22 \\
(2008)\end{array}$ & $\begin{array}{l}\text { ASA-ERDP } 25 / 200 \mathrm{mg} \\
\text { twice daily vs CLO } \\
75 \mathrm{mg} / \mathrm{d} \\
\text { Treatment/study } \\
\text { duration: mean } 2.5 \mathrm{y} \\
\text { (range } 1.4-4.4 \mathrm{y} \text { ) }\end{array}$ & $\begin{array}{l}\text { Within } 90 \mathrm{~d} \text { of } \\
\text { index event } \\
\text { Median time: } \\
15 \mathrm{~d}\end{array}$ & 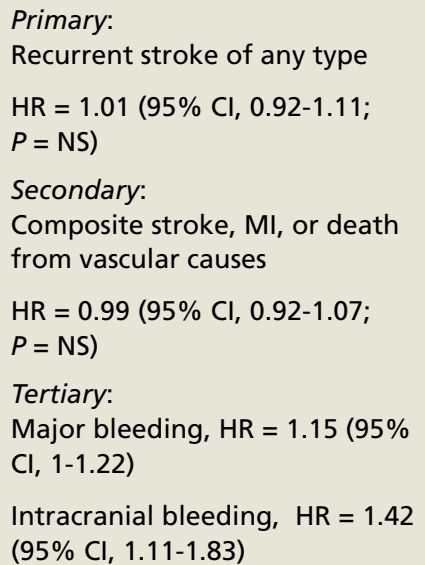 & $\begin{array}{l}\text { Major bleed } \mathrm{NNH}=193 \\
\text { Intracranial bleed NNH }=233 \\
\text { Underpowered } \\
10 \% \text { received CLO + ASA for } 8 \text { mo } \\
\text { before switching to CLO monotherapy }\end{array}$ \\
\hline
\end{tabular}

of stroke. Further evidence utilizing appropriate controls, timing, and assessment of confounders is needed. Additionally, ASAERDP is plagued by tolerability issues such as headache, nausea, and vomiting, leading to higher rates of discontinuation than its comparators in clinical trials. Accordingly, the maintenance use of ASA-ERDP for sec- ondary stroke prevention may be considered less preferred than other recommended alternatives such as aspirin or clopidogrel monotherapies.

JFP

\section{CORRESPONDENCE}

Robert S. Helmer, PharmD, BCPS, Department of Pharmacy Practice, Auburn University Harrison School of Pharmacy, 650 Clinic Drive, Suite 2100, Mobile, AL 36688; Rsh0011@auburn. edu. 
TABLE 2

Aspirin and extended-release dipyridamole for recurrent stroke: A summary of RCTs (cont'd)

\begin{tabular}{|c|c|c|c|c|}
\hline Trial & Intervention & $\begin{array}{l}\text { Time to } \\
\text { treatment } \\
\text { onset }\end{array}$ & Outcomes/results & Notes \\
\hline $\begin{array}{l}\text { EARLY }{ }^{23} \\
(2010)\end{array}$ & $\begin{array}{l}\text { Day 1-7: ASA-ERDP } \\
\text { 25/200 mg twice daily } \\
\text { vs ASA } 100 \mathrm{mg} / \mathrm{d} \\
\text { Day } 8-90: \text { ASA-ERDP } \\
\text { 25/200 mg twice daily, } \\
\text { both groups } \\
\text { Treatment/study } \\
\text { duration: } 90 \mathrm{~d}\end{array}$ & $\begin{array}{l}\text { Within } 24 \mathrm{hr} \text { of } \\
\text { index event }\end{array}$ & $\begin{array}{l}\text { Primary: } \\
\text { Functionality change at Day } 90 \\
-2 \text { vs }-2(P=N S) \\
\text { Secondary: } \\
\text { Composite safety and efficacy } \\
\text { HR }=0.73(95 \% \mathrm{Cl}, 0.44-1.19 \\
P=N S)\end{array}$ & $\begin{array}{l}\text { Mean NIHSS score }<4 \text { at baseline } \\
\text { indicated low-severity strokes } \\
\text { Results represent early vs late initiation } \\
\text { of ASA-ERDP }(<7 \mathrm{~d} \text { vs }>7 \mathrm{~d})\end{array}$ \\
\hline $\begin{array}{l}\text { TARDIS }{ }^{24} \\
(2018)\end{array}$ & $\begin{array}{l}\text { ASA-ERDP + CLO vs } \\
\text { CLO or ASA-ERDP } \\
\text { (guideline dosing) } \\
\text { Treatment/study } \\
\text { duration: } 90 \mathrm{~d}\end{array}$ & $\begin{array}{l}\text { Within } 48 \mathrm{hr} \text { of } \\
\text { index event }\end{array}$ & $\begin{array}{l}\text { Primary: } \\
\text { Incidence and severity of } \\
\text { recurrent stroke/TIA up to } 90 \mathrm{~d} \\
\mathrm{HR}=0.9(95 \% \mathrm{Cl}, 0.67-1.20 ; \\
P=\mathrm{NS}) \\
\text { Safety: All bleeding events } \\
20 \% \text { vs } 9 \%(P<.0001) \\
\text { Fatal bleed } 1 \% \text { vs }<1 \%(P=\mathrm{NS}) \\
\text { Minor bleed } 16 \% \text { vs } 7 \%\end{array}$ & $\begin{array}{l}\text { All bleeding } \mathrm{NNH}=10 \\
\text { Thrombolysis allowed, randomization } \\
\text { delayed } 24 \mathrm{hr} \text { after administration } \\
\text { Loading doses given }\end{array}$ \\
\hline
\end{tabular}

ASA, aspirin; CLO, clopidogrel; ERDP, extended-release dipyridamole; HR, hazard ratio; MI, myocardial infarction; NIHSS, National Institutes of Health Stroke Scale; NNH, number needed to harm; NNT, number needed to treat; NS, nonsignificant; RCTs, randomized controlled trials; SD, standard deviation; TIA, transient ischemic attack.

aHR for intention-to-treat arm

\section{References}

1. CDC. Stroke Facts. Last updated January 31, 2020. www.cdc.gov/ stroke/facts.htm. Accessed June 29, 2020.

2. Amarenco P, Lavallee PC, Labreuche J, et al. One-year risk of stroke after transient ischemic attack or minor stroke. $N$ Engl $J$ Med. 2016;374:1533-1542.

3. Amarenco P, Lavallee PC, Monteiro Tavares L, et al. Five-year risk of stroke after TIA or minor ischemic stroke. $N$ Engl J Med. 2018;378:2182-2190.

4. Johnston SC, Easton JD, Farrant M, et al. Clopidogrel and aspirin in acute ischemic stroke and high-risk TIA. N Engl J Med. 2018;379:215-225.

5. Wang Y, Wang Y, Zhao X, et al. Clopidogrel with aspirin in acute minor stroke or transient ischemic attack. $N$ Engl J Med. 2013;369:11-19.

6. Bowry AD, Brookhart MA, Choudhry NK. Meta-analysis of the efficacy and safety of clopidogrel plus aspirin as compared to antiplatelet monotherapy for the prevention of vascular events. $\mathrm{Am}$ J Cardiol. 2008;101:960-966.

7. Kernan WN, Ovbiagele B, Black HR, et al. Guidelines for the prevention of stroke in patients with stroke and transient ischemic attack: a guideline for healthcare professionals from the American Heart Association/American Stroke Association. Stroke. 2014;45:2160-2236.

8. Gent M, Beaumont D, Blanchard J, et al. A randomised, blinded, trial of clopidogrel versus aspirin in patients at risk of ischaemic events (CAPRIE). Lancet. 1996;348:1329-1339.

9. Lansberg MG, O'Donnell MJ, Khatri P, et al. Antithrombotic and thrombolytic therapy for ischemic stroke: Antithrombotic therapy and prevention of thrombosis, 9th ed: American College of Chest Physicians Evidence-Based Clinical Practice Guidelines. Chest. 2012;141(2 suppl):e601S-e636S.
10. Johnston SC, Amarenco P, Denison H, et al. The acute stroke or transient ischemic attack treated with ticagrelor and aspirin for prevention of stroke and death (THALES) trial: rationale and design. Int J Stroke. 2019;14:745-751.

11. Powers WJ, Rabinstein AA, Ackerson T, et al. 2018 Guidelines for the early management of patients with acute ischemic stroke: a guideline for healthcare professionals from the American Heart Association/American Stroke Association. Stroke. 2018 49:e46-e110.

12. Diener HC, Bogousslavsky J, Brass LM, et al. Aspirin and clopidogrel compared with clopidogrel alone after recent ischaemic stroke or transient ischaemic attack in high-risk patients (MATCH): randomised, double-blind, placebo-controlled trial Lancet. 2004;364:331-337.

13. Benavente OR, Hart RG, McClure LA, et al. Effects of clopidogrel added to aspirin in patients with recent lacunar stroke. $N$ Engl Med. 2012;367:817-825.

14. Hankey GJ, Johnston SC, Easton JD, et al. Effect of clopidogrel plus ASA vs. ASA early after TIA and ischaemic stroke: a substudy of the CHARISMA trial. Int J Stroke. 2011;6:3-9.

15. Kennedy J, Hill MD, Ryckborst KJ, et al. Fast assessment of stroke and transient ischaemic attack to prevent early recurrence (FASTER): a randomised controlled pilot trial. Lancet Neurol. 2007;6:961-969.

16. LiZ, Wang Y, Zhao X, et al. Treatment effect of clopidogrel plus aspirin within 12 hours of acute minor stroke or transient ischemic attack. J Am Heart Assoc. 2016;5:e003038.

17. Scott SA, Sangkuhl K, Stein CM, et al. Clinical pharmacogenetics implementation consortium guidelines for CYP2C19 genotype and clopidogrel therapy: 2013 update. Clin Pharmacol Ther. 2013;94:317-323 
18. Wang Y, Zhao X, Lin J, et al. Association between CYP2C19 lossof-function allele status and efficacy of clopidogrel for risk reduction among patients with minor stroke or transient ischemic attack. JAMA. 2016;316:70-78.

19. Diener HC, Cunha L, Forbes C, et al. European Stroke Prevention Study 2. Dipyridamole and acetylsalicylic acid in the secondary prevention of stroke. J Neurol Sci. 1996;143:1-13.

20. Li X, Zhou G, Zhou X, et al. The efficacy and safety of aspirin plus dipyridamole versus aspirin in secondary prevention following TIA or stroke: a meta-analysis of randomized controlled trials. $J$ Neurol Sci. 2013;332:92-96.

21. Halkes PH, van Gijn J, Kapelle IJ, et al. Aspirin plus dipyridamole versus aspirin alone after cerebral ischaemia of arterial origin (ESPRIT): randomised controlled trial. Lancet.
2006;367:1665-1673.

22. Sacco RL, Diener HC, Yusuf S, et al. Aspirin and extended-release dipyridamole versus clopidogrel for recurrent stroke. $N$ Engl Med. 2008;359:1238-1251.

23. Dengler R, Diener HC, Schwartz A, et al. Early treatment with aspirin plus extended-release dipyridamole for transient ischaemic attack or ischaemic stroke within $24 \mathrm{~h}$ of symptom onset (EARLY trial): a randomised, open-label, blinded-endpoint trial. Lancet Neurol. 2010;9:159-166.

24. Bath PM, Woodhouse LJ, Appleton JP, et al. Antiplatelet therapy with aspirin, clopidogrel, and dipyridamole versus clopidogrel alone or aspirin and dipyridamole in patients with acute cerebral ischaemia (TARDIS): a randomised, open-label, phase 3 superiority trial. Lancet. 2018;391:850-859.

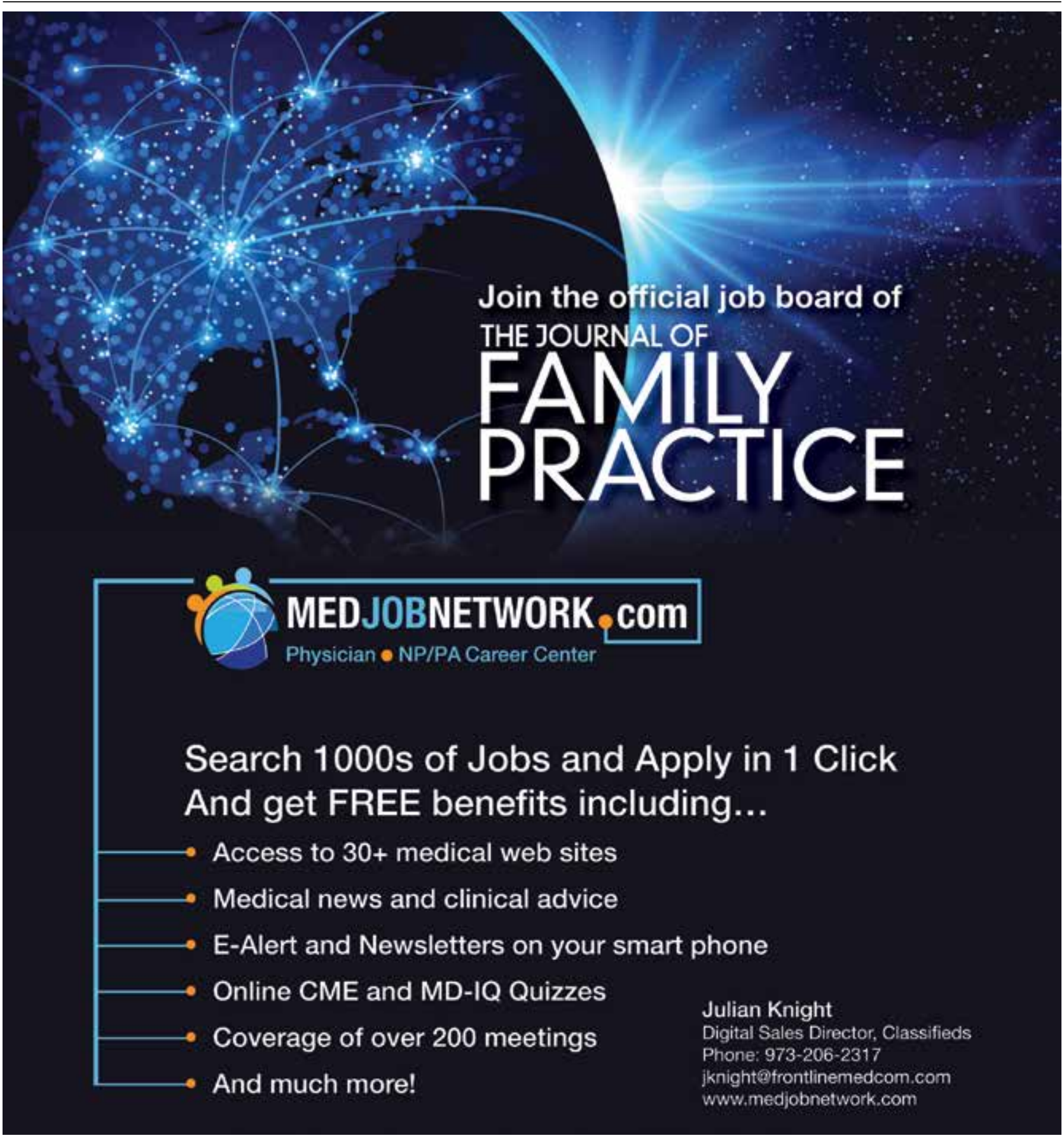

